Магдисюк Людмила

кандидат психологічних наук,

доцент кафедри практичної та клінічної психології Східноєвропейського національного університету імені Лесі Українки; http://orcid.org/0000-0002-5304-933X

Притка Іванна

здобувач першого (бакалаврського) рівня 4-го курсу факультету психології та соціології Східноєвропейського національного університету імені Лесі Українки http://orcid.org/0000-0001-5977-202X DOI https://doi.org/10.35619/prap_rv.vi14.162

\title{
ПСИХОЛОГІЧНІ ОСОБЛИВОСТІ ПРОЯВУ САМОТНОСТІ У ЮНАЦЬКОМУ ВІЦІ
}

Анотація. В статті представлено теоретичний аналіз досліджень самотності, а також дані емпіричного дослідження даного феномену у осіб юнацького віку. Факторами, щзо обумовлюють актуальність вивчення даного психологічного явища є різкий скачок популярності соиіальних мереж серед молоді, тенденція до урбанізачії та особливості перебігу вікових періодів розвитку особистості. Часто самотність вважається проблемою старших поколінь, але у сучасному світі, із розвитком технологій та можливістю інтернет-спілкування, все частіше саме молодь у юнацькому віці гостро відчуває себе самотньою. Існує стереотип, щуо самотніми стають лише ті, хто не знає, як спілкуватись з людьми, або як поводитись з оточенням. Але дослідження показали, щзо сочіальні навички ніяк не впливають на сочіальні зв'язки. Протягом довгого часу самотність розглядалась вченими як негативне явище, щуо може шкодити не лише психіці, а й фізичному здоров'ю людини. Період юнацтва характеризується пошуком свого місия 8 світі та суспільстві, бажанням само-ідентифікуватися, усамітнитись (Vanhalst, Gibb, 2015; Weiss, Bowlby, Parkes, 1973). Перехід від навчання в школі до університету часто супроводжується переїздом у нове місто, потребою у налагодженні нових соціальних зв 'язків. У роботі відображено переоцінку самотності як явища, що несе в собі позитивний зміст та ресурс для самовдосконалення особами юнащького віку. У статті висвітлено особливості формування відчуття самотності у молоді юнацького віку; етапи розвитку уявлень про феномен самотності; вилив самотності як ресурсного явища у етапі формування особистості.

Ключові слова: психосоматичні розлади, самотність, юнацтво, самовизначення, ресурс, підлітки, соціалізація, самоідентифікащія, ізолячүія, усамітнення.

Постановка проблеми. Самотність - одна із найважчих для сучасної людини психологічних проблем. Дане поняття являється найменш дослідженим серед соціальних явищ. Потрібно зауважити, що період юнацтва відіграє важливу роль у процесі розвитку особистості та соціалізації. Саме тому проблема самотності молодих осіб має велике значення. Дослідження, що проводились, сформували у більшості стале негативне уявлення щодо даного феномену. Сучасний світ, натомість, вимагає від нас переоцінки самотності, як ресурсу для самовдосконалення та формування індивідуальності.

Аналіз останніх досліджень 3 проблеми. Проблема самотності досліджувалась у працях західних і американських філософів, психологів, соціологів, медиків, письменників тощо, таких як: Бубер, Вулф, Вейс, Гессе, Грін, Дефо, Камю, Мід, Міюскович, Мустакас, Пепло, Рассел, Садлер, Салліван, Сартр, Фромм, Янг, Ялом, та багатьох інших. Українські вчені та їх колеги 3 держав, що утворилися на теренах колишнього СРСР до проблеми самотності зверталися рідко. Окремі публікації з'явилися лише в останні десятиліття XX сторіччя. Це праці Ачилдієва, Данчевої, Кошелєвої, Хамітова, Хараша, Харламенкової, Тіхонова, Швалба, та інших (Ноjat, \& Alonzo, 1989). 
Мета статті. Метою роботи є проведення аналізу теоретичних відомостей про психологічні прояви самотності, проведення аналізу емпіричного дослідження виявлення специфіки перебігу даного стану в осіб юнацького віку та переоцінка явища самотності як ресурсу для розвитку особистості.

Виклад основного матеріалу. У ході розвитку уявлень про самотність умовно можна виокремити чотири основних етапи. Перший етап характеризується нечіткими уявленнями про самотність, в основному на рівні роздумів, а також згадок в теологічній та художній літературі (Гасанова, \& Омарова, 2017, с. 76).

Другий етап бере свій початок на початку XIX століття та тривав до десятих-двадцятих років XX століття. В цей період формуються філософські основи вивчення самотності. Дана тема стійко закріплюється в художній літературі серед письменників, поетів та музикантів (Гасанова, \& Омарова, 2017, с. 76).

Третій етап припадає на кінець 30 - $\mathrm{x}$ - середину 80 -х років минулого століття. В цей період вибудовуються концептуальні основи феноменологічних досліджень, тема самотності людини стає центральною у літературних творах таких авторів, як Камю, Гессе, Ремарк, Маркес та інші. На відміну від першого та другого етапів, третій має чіткі межі свого початку. 1938 рік став роком публікації результатів досліджень Л. Зілбурга та його колег в рамках психодинамічної парадигми (Гасанова, \& Омарова, 2017, с. 76).

На сьогоднішній день безумовна більшість авторів, які висвітлюють проблему самотності, сходяться на тому, що самотність пов'язана 3 переживанням людиною їі відірваності від спільноти людей, історії, сім'ї, природи, культури. Нерідко вказується, що сучасна людина відчуває самотність найбільш гостро в ситуаціях інтенсивного примусового спілкування (Гасанова, \& Омарова, 2017, с. 76; Ernst, Cacioppo, \& Hawkley, 2002, с. 63). Рокач (1997) визначив 5 найпоширеніших причин самотності: особисті недоліки; проблеми розвитку; нереалізовані міжособистісні відносини; переселення або соціальний поділ; соціальна маргіналізація. Ці причини охоплюють великий спектр факторів, від вроджених, особистих до фінансових i соціальних. Історична концептуалізація самотності привела сучасну психологію до трьох основних конструктів, афективної складової, когнітивної складової та суб'єктивної складової. Ці три компоненти представлені трьома психологічними підходами: психодинамічними, пізнавальними та екзистенціальними (Sonderby, \& Wagoner, 2013).

Розглянемо перший підхід, що грунтується на психодинамічній теорії та пов'язаний із соціальними потребами. Дане розуміння самотності базується на прихильності дитини до матері. Завдяки цій прихильності дитина вчиться емоційним зв'язкам і тому, як контактувати з іншими. Відчуття самотності виникає в неї в наслідок відсутності живого контакту із важливими особами (Sonderby, \& Wagoner, 2013). Вчені, прихильники психоаналітичного напрямку, які опирались на появу патологічної поведінки в ранньому дитинстві, були попередниками підходу, що базувався на соціальних потребах, вони формували теоретичні та концептуальні знання щодо феномену самотності (Корчагіна, 2005, с. 196). Більш сучасне розуміння бачиться в роботі Мохаммадреги Ходжат, серед іншого, який підкреслює самотність як патологічний стан через розпад соціальних потреб у ранньому дитинстві та пізніх інтрапсихічних конфліктах (Hojat, \& Alonzo, 1989).

Когнітивний підхід грунтується на моделі розбіжності між бажаними та фактичними соціальними відносинами: самотність є результатом реакції психіки на розбіжності між бажаним та досягнутим рівнем соціального контакту: варто зауважити, що когнітивні процеси мають формуючий вплив на особливості переживання самотності (Peplau, \& Perlman, 1982, c.187).

Екзистенціальна психологія подає тлумачення самотності виділяючи в ній різні види. Основною тут виступає екзистенціальна самотність, тобто така, що є частиною людського стану. Існує також інший вид, він виникає в наслідок тривожності. Екзистенційна самотність $\epsilon$ внутрішньою і органічною реальністю людського життя, в якій виникає і біль, і тріумфальне творення, що виникають в періоди спустошення. В ній людина повністю усвідомлює себе як ізольованого і самотнього індивідуума. Самотність в наслідок тривожності викликає відчуття відчуження від себе самого, своїх переживань, емоцій та почуттів (Weiss, Bowlby, \& Parkes, 1973).

Література висвітлює емоційну природу самотності, як відчуття із негативним спектром емоційних реакцій. Але сучасні дослідження покликані запропонувати комплексну модель та 
перелік характеристик, що можуть свідчити про вищий або нижчий рівень ризику для розвитку «хронічної самотності». Оцінюючи характер впливу самотності на життя людини, варто підкреслити, що існує певна полярність. Не зважаючи на переважно негативне відображення даного явища, самотність розглядається і як обов'язковий етап у формуванні самовизначення та індивідуальності (Пепло, \& Перлман, 1989). Конструктивною стороною самотності заведено вважати іiі значення як необхідного етапу внутрішнього переосмислення, пізнання загального людського буття. Варто зауважити, що велика кількість психологів наголошує на важливості розмежування таких понять як «самотність» та «ізоляція», оскільки вони носять різний психологічний зміст. На думку Пепло, Міцеліо і Мораш, самотність не завжди викликає негативні переживання у людей і вони здатні бути щасливими, перебуваючи наодинці з собою і не надто перейматись самотністю (Пепло, \& Перлман, 1989). У літературі також виокремлюють термін «усамітнення». Його описують як ізоляція від інших, що не несе неприємного емоційного забарвлення. Усамітнення розглядається як конструктивний стан взаємодії людини із собою (Наталушко, 2008). Сучасна психологія все частіше говорить про користь усамітнення, оскільки воно відкриває простір для росту, дає глибоким роздумам, можливість пізнавати та вивчати себе, розвивати внутрішню рефлексію.

Неумоєва (2004) говорить, про позитивне усвідомлення самотності. Нею було розроблено типологізація видів суб'єктивного пережиття самотності. В основі лежать: індивідуальне сприйняття самотності та суб'єктивне ставлення до неї (позитивне і негативне); причини, якими викликаний даний стан (зовнішні фактори чи обставини або особистий вибір). На основі цих характеристик Неумоєва виділила різні види самотності: суб'єктивна негативна, обумовлена особистісним вибором (інтернальна негативна); суб' єктивна негативна, обумовлена зовнішніми чинниками (екстернальна негативна); суб'сктивна позитивна, обумовлена зовнішніми чинниками (екстернальна позитивна); суб'єктивна позитивна, обумовлена особистісним вибором (інтернальна позитивна) (с.23-29). Іншу класифікацію ми можемо зустріти у працях Корчагіної (2005, с.196). Вона вважала, що переживання самотності може мати негативне суб'єктивне забарвлення, тоді варто говорити про відчуження, або позитивне - усамітнення, вивільнення. Видова класифікація, запропонована Корчагіною, виглядає наступним чином: відчужена самотність, само-відчужена самотність, усамітнення (2005, с. 196). Демографічні характеристики також пов'язані з різним рівнем переживанням самотності: гендер (особливо вразливі чоловіки), старший вік і нижчий соціально-економічний статус виявились пов'язані зі збільшенням відчуття самотності. Вікові показники показують інтригуючу «аномалію», що проявляється у тому, що самотність має тенденцію до максимуму в підлітковому та старечому віці.

Потрібно зауважити, що юнацтво відіграє важливу роль у процесі розвитку особистості та соціалізації. Тому проблема самотності молодих осіб має велике значення. Період «нормативної кризи», саме таким терміном Еріксон (2006, с. 342) визначає юнацький вік. Дана криза характеризується набуттям особистістю ідентичності, тобто психосоціальної тотожності. Такі зміни в психологічних структурах супроводжуються оцінкою своїх слабких та сильних сторін, здобуттям навичок використання їх, щоб отримати чіткі уявлення про свої перспективи та про себе самого. Слободчиков та Ісаєв (Токарева, \& Шамне, 2013, с. 283) пов'язують цей період із переходом до самостійного життя і власної відповідальності за нього.

У вітчизняній психології заведено виділяти такі центральні новоутворення психіки, як; особистісне самовизначення, потреба у внутрішньому оволодінні позиції дорослої людини, усвідомлення власного місця в суспільстві, оцінка своїх можливостей. Західні психологи визначають вище перераховані ознаки терміном «ідентичність» (Токарева, \& Шамне, 2013, с. 283; Еріксон, 2006, с. 342). Ідентичність за Еріксоном розглядається як психосоціальна тотожність, суб'єктивне почуття особистої самототожності й безперервності (сталості), яке дозволяє особистості усвідомлювати себе у своєму ставленні до навколишнього середовища і визначає систему ідеалів, життєвих перспектив, цінностей, соціальних ролей із відповідними формами поведінки. Еріксон стверджує, що ідентичність індивіда грунтується на двох спостереженнях, які існують водночас: відчутті тотожності самому собі та неперервності свого існування в часі і просторі, а також того факту, що твоя ідентичність визнається іншими (Токарева, \& Шамне, 2013, c. 283). У період юнацтва молоді люди зустрічаються з кризою сенсу життя, яка зумовлює: пошук 
власного місця у системі соціальних стосунків; критичне сприймання спільного із дорослими життєвого простору; прагнення до самовизначення (професійного, особистісного, індивідуального) та самореалізації; актуалізацію потреби у самоповазі; юнацький максималізм (Еріксон, 2006 с. 342).

Як зазначила Неумоєва, основні процеси самосвідомості в юнацькому періоді тісно пов'язані з переживанням самотності (2004, с. 23-29). Це має вплив на формування у особи ставлення до себе (емоційні прояви самотності), уявлення про себе , як особистість (когнітивні прояви самотності), на особливості характеру і вибір моделей поведінки (поведінкові прояви самотності). За словами Неумоєвої, особа, що переживає самотність, вбачає невідповідність між собою в даний момент і тим образом, якому хоче відповідати. В цьому, на її думку, полягає позитивний ефект даного феномену, оскільки усвідомлюючи невідповідність, особа починає мобілізувати сили для саморозвитку. Позитивним можна назвати й те, що самотність може слугувати індикатором незадовільної життєвої ситуації, що склалась. Цим самим спонукаючи людину до змін і розвитку свого внутрішнього потенціалу (2004, с. 23-29). У контексті юнацтва, самотність може бути пов'язана із такими подіями життя, як: переїзд з батьківського дому, збільшення контексту соціальних відносин, потреба у пануванні майбутнього, побудова інтимних особистісних стосунків.

На основі типології, розробленої Неумоєвою, юнацька самотність визначалась як «інтернально позитивний» процес: «...юнак, на відміну від підлітка, починає розуміти або інтуїтивно вгадує значущу позитивну роль самотності в становленні своєї особистості і може свідомо вибирати самотність» (Неумоева, 2004, с. 23-29). Позитивне ставлення юнацтва до самотності має конструктивний зміст та вмотивованість. Оскільки це дає можливість вільно розпоряджатись своїми інтересами, вподобаннями і потребами. В такому стані усамітнення відкривається можливість до самодослідження і самовизначення.

Отже, досліджуючи особливості формування психіки у юнацький період, ми прийшли до висновків, що на цьому віковому етапі загострюються потреби у пошуку власного «Я», самореалізації, усамітненні з ціллю інтроспективного спостереження за своїми реакціями та емоціями. Ці чинники можуть виступати факторами появи відчуття самотності, але за умови правильного підходу до подолання негативних наслідків даного феномену, самотність може виступати позитивним явищем у період юнацтва.

Базуючись, на проведеному нами теоретичному дослідженні, було проведено емпіричне дослідження, яке було спрямоване на виявлення рівня та виду самотності у молоді. Базою для проведення емпіричного дослідження було обрано учнів Луцького навчально-виховного комплексу №9. Вибірку становило 24 учні 10 класу (12 - дівчат, 12 - хлопців). Основною характеристикою вибірки була вікова категорія, до якої належать респонденти (15-16 років).

При аналізі даних методики виявлення суб'єктивного відчуття самотності було помічено різницю показників за статевою приналежністю. Як бачимо з рис. 1, дівчата виявились більш схильними до переживання даного стану. 66,4\% досліджуваних дівчат відчувають самотність. При цьому 50\% переживають середній рівень, а 16,4\% - високий рівень. Результати інших 33,6\% дали низькі показники цього відчуття. Натомість, серед хлопців лише $16,4 \%$ відчувають середній рівень самотності, 83,6\% не перейшли межу низького рівня і жоден із респондентів чоловічої статі не відзначився високим рівнем самотності.

Такий розподіл результатів вказує на наявність різниці між сприйняттям самотності у дівчат та хлопців. На це можуть впливати як зовнішні фактори (особливості культури виховання та ін.), так і внутрішні (індивідуальні якості характеру, темперамент тощо). Причиною такого результату також може бути різниця в особливостях вікового розвитку осіб юнацького віку в залежності від статевої приналежності. 


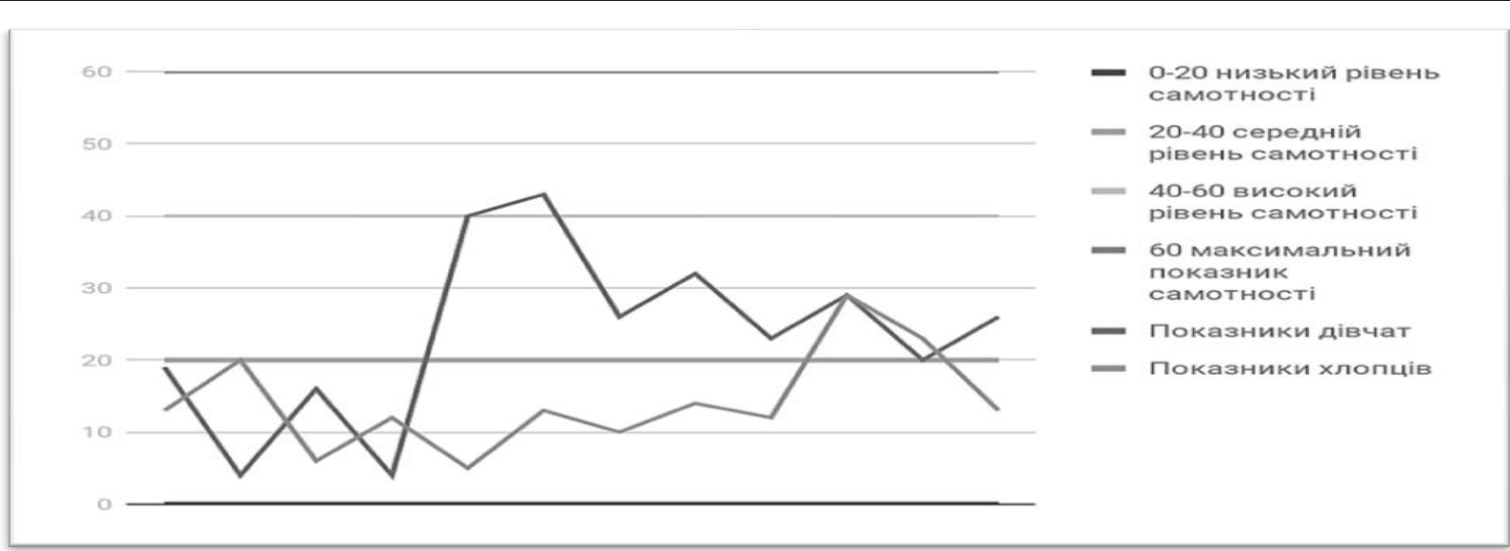

Рис. 1 Розподіл рівнів самотності досліджуваних за статевою приналежністю «Методика діагностики рівня суб'єктивного відчуття самотності» (авт.Рассел і Фергюсон)

Даючи загальну характеристику, за методикою діагностики рівня суб'єктивного відчуття самотності, варто зауважити, що 54,2\% опитуваних не відчувають себе самотніми, переживання середньої самотності притаманне 37,5\%, незначна частина опитуваних, 8,3\% - переживає відчуття високої самотності. Це говорить, про переважно хорошу стійкість представників вибірки до негативного сприйняття самотності. Їхнє суб'єктивне бачення даного стану не виявляє негативного впливу на загальний стан, самопочуття, сприйняття себе та оточуючих.

Щоб визначити вид і глибину переживання самотності, респондентам було запропоновано пройти «Опитувальник для визначення виду самотності» (Корчагіна). У опитувальнику виділено 4 шкали, що відповідають 4 видам самотності (дифузна самотність, відчужена самотність, дисоціативна самотність, стан самотності без певного виду). За показниками дифузної самотності максимально набраний відсоток цього виду спостерігається у 2 осіб і становить 77,7\%; результати, що зустрічаються найчастіше $38,8 \%$, такий відсоток виявлено у 5 осіб та 33,3\% також 5 осіб; найнижчий показник складає 16,6\% - 2 особи. Відчужений вид самотності у відсотковому значені 50\% переживає 6 респондентів, це найпоширеніший рівень прояву, максимальний показник 71,4\% - 2 особи, мінімальний рівень прояву відчуження у 4 досліджуваних $-35,7 \%$. Найпоширенішим станом самотності виявилась самотність без конкретного виду. 73,3\% становить максимальний рівень, його переживає 2 особи, мінімальний рівень - 26,6\% (3 особи). Найпоширеніший показник- 33,3\% (5 осіб). Дисоційований вид самотності був переважаючим у найменшої кількості досліджуваних. Але саме він мав найвищий рівень прояву серед усіх вище зазначених. Максимальний рівень прояву було виявлено у 1 особи 3 показником у 92,2\%. Найпоширеніший результат складає 50\% - 7 осіб, мінімальний прояв дисоційованого виду у 2 осіб - 28,5\%.

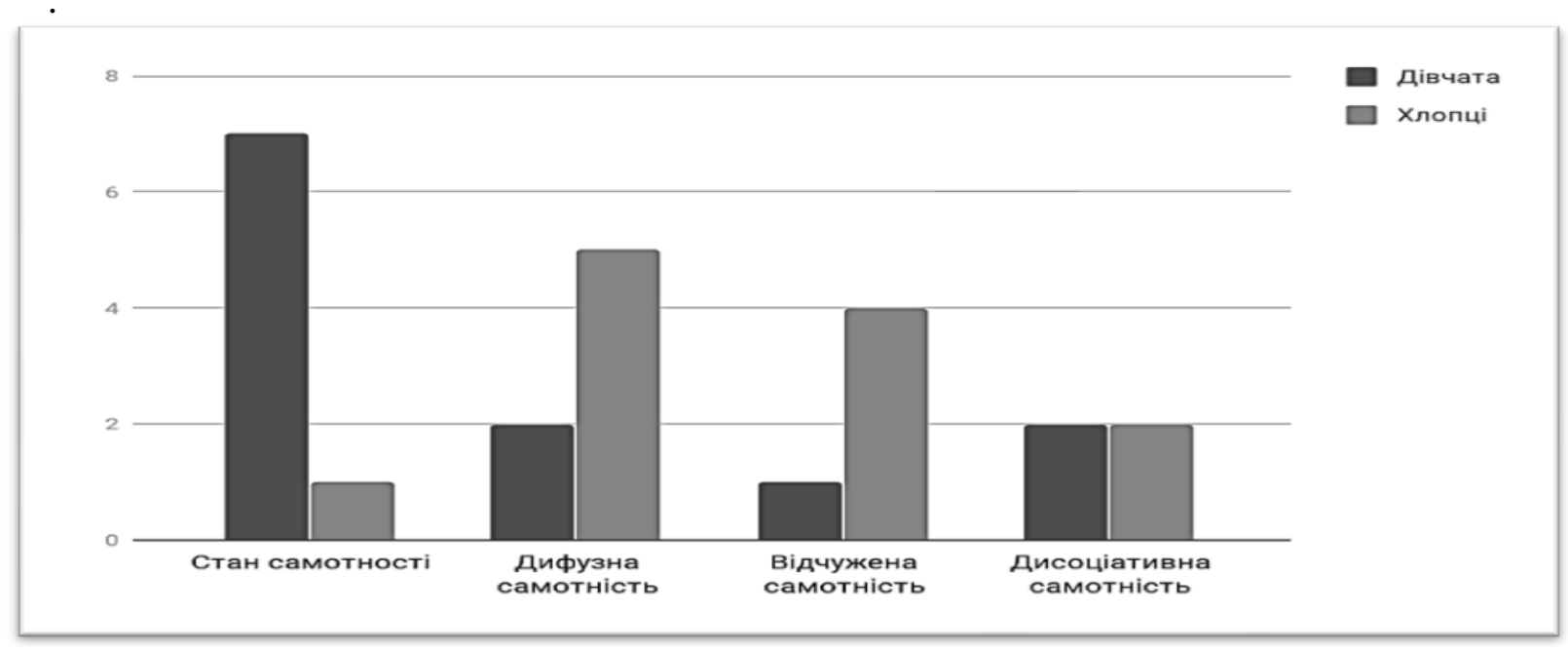

Рис. 2. Відмінності показників співвідношення рівнів самотності за статевою ознакою "Опитувальник для визначення виду самотності» (авт. Корчагіна) 
Оцінка результатів, за гендерною ознакою, що представлена на рис. 2, показала, що дівчатам більшою мірою характерно переживати стан самотності невизначеного виду $(58,3 \%$ дівчат, 8,3\% хлопців). Такий стан характеризується загальним переживанням відчуття самотності 3 відсутністю домінуючих ознак того чи іншого виду, або без характерних особливостей прояву. Натомість у хлопців спостерігається тенденція до переживання дифузного (41,6\% хлопців, 16,6\% дівчат) та відчуженого (33,3\% хлопців, 8,3\% дівчат) виду самотності. Як зазначалось вище, особливостями дифузного виду $є$ ідентифікація себе 3 іншими. Можемо припустити, що поясненням такої тенденції може бути бажання юнаків бути частиною референтної для них групи. У однакового відсотка (16,6\%) дівчат та хлопців виявлено дисоційований вид самотності.

Висновки та перспективи подальших розвідок. Вивчення наукових джерел, що розглядали позитивні та негативні наслідки самотності, дають можливість зробити висновок, що до недавніх пір, самотність носила негативне забарвлення і більшість праць психологів були спрямовані на вивчення деструктивності даного явища. Лише 3 кінця XX століття, психологи запропоновали інший підхід, для переосмислення якості самотності як ресурсу. Змінюючи своє суб'єктивне ставлення до самотності, особи, що потерпали від негативних проявів цього стану, зможуть переоцінити свій стан та більш ефективно використовувати власні можливості. Проведене емпіричне дослідження показало, що психологічні особливості переживання стану самотності у молоді юнацького віку мають характерні гендерні відмінності.

Підсумовуючи роботу, можемо зауважити, що обрана нами тема $\epsilon$ актуальною для подальших досліджень. Полем для роботи може розробка методів та технік, спрямованих на перебудову суб’єктивної оцінки самотності, як негативного феномену та популяризації позитивних поглядів на усамітнення, як ресурс до самовдосконалення.

\section{СПИСОК ПОСИЛАНЬ}

Гасанова, П. Г., \& Омарова, М. К. (2017). Психология одиночества. Київ: Финансовая Рада Украины.

Гусейнова, Н. О. (2014). Самотність як ресурс особистісного розвитку. Гуманітарний вісник Переяслав-Хмельницького державного педагогічного університету імені Г. С. Сковороди: Збірник наукових пращь. Переяслав-Хмельницький.

Корчагина, С. Г. (2005). Генезис, виды и проявления одиночества. Москва: МПСИ.

Наталушко, I. Ю. (2008). Самотність та усамітнення через призму творчості. Практична психологія та сочіальна робота, 3, 13-17.

Неумоева, Е. В. (2004). Одиночество как общественно-историческое явление и как явление индивидуальной жизни. Чита: ЗабГПУ.

Пепло, Л. Е. (1989). Лабиринты одиночества: Теоретические подходы к одиночеству. Москва: Прогресс.

Токарева, Н. М., \& Шамне, А. В. (2013). Основи вікової психології: Навчально-методичний посібник. Кривий Ріг.

Хамитов, Н. (2001). Философия и психология пола. Киев: Ника-Центр, Москва.

Эриксон, Э. (2006). Идентичность: юность и кризис. Москва: Флинта.

Ernst, J. M., Cacioppo, J. T., \& Hawkley, L. C. (2002). Psychosomatic Medicine: Loneliness and health.

Hojat, M., \& Alonzo, A. (1989). Contemporary Sociology: Loneliness: Theory, Research and Applications.

Peplau, L. A., \& Perlman, D. (1982). Loneliness: A sourcebook of current theory, research and therapy: Perspectives on loneliness. New York.

Rokach, A. (1997). Relations of perceived causes and the experience of loneliness.

Sønderby, L. C., \& Wagoner, B. (2013). Journal of Integrated Social Sciences: loneliness: an integrative approach.

Vanhalst, J., Gibb, B. \& Prinsteind, M. (2015). Lonely adolescents exhibit heightened sensitivity for facial cues of emotion.

Weiss, R. S., Bowlby, J., \& Parkes, J. C. (1973). Loneliness: The experience of emotional and social isolation. Cambridge, MA: MIT Press. 


\section{REFERENCES}

Gasanova, P. G., \& Omarova. M. K. (2017). Psychologiya odinochestva [Psychology of loneliness]. Kyiv: Finansovaya Rada Ukrainy. [in Rassian].

Guseynova, N. O. (2014). Samotnist yak resurs osobistisnogo rozvitku [Loneliness as a resource for personal development]. Gumanitarniy visnik Pereyaslav-Hmelnitskogo derzhavnogo pedahohichnogo universytetu imeny G. S. Skovorodi: Zbirnyk naukovyh prats'. PereyaslavHmelnitskiy. [in Ukrainian].

Korchagina, S. G. (2005). Genesis, vidy i proyavleniya odinochestva [Genesis. types and manifestations of loneliness]. Moskva: MPSI. [in Rassian].

Natalushko, I. Yu. (2008). Samotnist' ta usamitnennya cherez prizmu tvorchosti [Loneliness and solitude through the prism of creativity]. Practical psychology and social work, 3, 13-17. [in Ukrainian].

Neumoyeva, E. V. (2004). Odinochestvo kak obshchestvenno-istoricheskoye yavleniye i kak yavleniye individualnoy zhizni [Loneliness as a socio-historical phenomenon and as a phenomenon of individual life]. Chita: ZabGPU. [in Rassian].

Peplo, L. E. (1989). Labirinty odinochestva: Teoreticheskiye podhodi $k$ odinochestvu [Labyrinths of loneliness: Theoretical approaches to loneliness]. Moskva: Progress. [in Rassian].

Tokareva, N. M., \& Shamne, A. V. (2013). Osnovy vikovoyi psikhologiyi: Navchalno-metodichnyi posibnyk [Fundamentals of Age Psychology: Tutorial]. Kriviy Rig. [in Ukrainian].

Hamitov, N. (2001). Filosofiya i psihologiya pola [Philosophy and Psychology of Sex]. Kyiv: NikaTsentr, Moskva. [in Rassian].

Erikson. E. (2006). Identichnost': yunost' i krizis [Identity: Youth and Crisis]. Moskva: Flinta. [in Rassian].

Ernst, J. M., Cacioppo, J. T., \& Hawkley, L. C. (2002). Psychosomatic Medicine: Loneliness and health. [in English].

Hojat, M., \& Alonzo, A. (1989). Contemporary Sociology: Loneliness: Theory, Research and Applications. [in English].

Peplau, L. A., \& Perlman, D. (1982). Loneliness: A sourcebook of current theory, research and therapy: Perspectives on loneliness. New York. [in English].

Rokach, A. (1997). Relations of perceived causes and the experience of loneliness. [in English].

Sønderby, L. C., \& Wagoner, B. (2013). Journal of Integrated Social Sciences: loneliness: an integrative approach. [in English].

Vanhalst, J., Gibb, B. \& Prinsteind, M. (2015). Lonely adolescents exhibit heightened sensitivity for facial cues of emotion. [in English].

Weiss, R. S., Bowlby, J., \& Parkes, J. C. (1973). Loneliness: The experience of emotional and social isolation. Cambridge, MA: MIT Press. [in English].

\section{PSYCHOLOGICAL PECULIARITIES OF MANIFESTATION IN YOUTH AGE}

Liudmyla Mahdysiuk

Candidate of Psychological Sciences, Associate Professor of the Department of Practical and Clinical Psychology Lesya Ukrainka Eastern European National University; http://orcid.org/0000-0002-5304-933X

Ivanna Prytka

student of the 4th year of the Faculty of Psychology and Sociology

Lesya Ukrainka Eastern European National University http://orcid.org/0000-0001-5977-202X

DOI https://doi.org/10.35619/prap_rv.vi14.162 
Abstract. In this article theoretical analysis of researches of loneliness is presented as well as empirical research of this phenomenon among the young people. The main factors that prove the relevance of the study of this psychological phenomenon are the prompt increasing of social media popularity among the youth, urbanization tendency and the peculiarities of some age periods of personality development. The loneliness often is considered to be the problem of older generation, but in the modern world with technology development and high online-communication possibilities, youth feel themselves lonely more often. There is a stereotype, that only the people who do not know how to communicate with people can be lonely. However, the researches showed that social skills have no impact on social connections. For the long time loneliness was considered by scholars as a negative phenomenon, that can harm not only the mental state but also physical health of the person. The period of adolescence is characterized by the search of its place in the world and society and the willing of selfidentification, privacy (Vanhalst, Gibb, 2015; Weiss, Bowlby, Parkes, 1973).

The move from the school to university that often is followed by moving to other town and necessity to set the new social connections. During the research of the mental state forming in the period of adolescence, it is important to note that in this age the necessity of self-identification, self-realization, and solitude in order of introspective observation of their own reactions and emotions is emphasized. These factors can be the cause of loneliness but in case of the right approach to overcoming the negative consequences of this phenomenon, loneliness can be a positive phenomenon in the period of adolescence. A positive attitude of youth to loneliness has rational content and motivation. Because this attitude gives the possibility to manage their own interests, preferences, and needs. In the state of solitude, the possibilities of self-investigation and self-identification are being developed.

In this work loneliness is reflected as a phenomenon the has the positive content and is the source for self development by young people. The peculiarities of the feeling of loneliness in youth; the stages of development of image of loneliness phenomenon; the impact of loneliness as the phenomenon of resource on the stage of personality formation.

Key words: psychosomatic disorders, loneliness, adolescence, self identification, resource, teenagers, socialization, self determination, isolation, privacy. 